\title{
The effect of fluticasone on the airway inflammatory response to organic dust
}

\author{
A. Ek*,\#, L. Palmberg*, K. Larsson*
}

The effect of fluticasone on the airway inflammatory response to organic dust. A. Ek, L. Palmberg, K. Larsson. (C) ERS Journals Ltd 2004.

ABSTRACT: Exposure to organic dust in a swine house causes acute airway inflammation and increased bronchial responsiveness to methacholine in healthy subjects. The aim of this study was to investigate whether an inhaled glucocorticoid, fluticasone propionate, alters the acute airway responses induced by exposure in a swine barn.

In 15 healthy subjects, analysis of nasal lavage fluids, serum samples and bronchial methacholine responsiveness were performed before and after exposure to organic dust in a swine house for $3 \mathrm{~h}$. Seven subjects received fluticasone propionate $(500 \mu \mathrm{g}$ b.i.d. by inhalation and $100 \mu \mathrm{g}$ intranasally once daily) and eight subjects received placebo during the 2 weeks prior to exposure.

Post-exposure plasma interleukin (IL)-6 levels and body temperature were significantly lower in the fluticasone group than in the placebo group. Intranasally administered fluticasone propionate significantly attenuated the plasma protein (assessed as albumin concentrations) leakage and IL-8 and tumour necrosis factor- $\alpha$ response induced by exposure. Fluticasone propionate inhalation exerted no influence on the increased bronchial responsiveness to methacholine induced by exposure.

In conclusion, glucocorticoid treatment attenuated the inflammatory response to inhaled organic dust without influencing the increased bronchial responsiveness to methacholine.

Eur Respir J 2004; 24: 587-593.
*Lung and Allergy Research, Division of Physiology, Institute of Environmental Medicine, Karolinska Institute, and ${ }^{\#}$ National Institute for Working Life, Stockholm, Sweden.

Correspondence: A. Ek, Lung and Allergy Research, Division of Physiology, Institute of Environmental Medicine, Karolinska Institutet, PO Box 287, SE-171 77 Stockholm, Sweden.

Fax: 468300619

E-mail: alexandra.ek@imm.ki.se

Keywords: Bronchial responsiveness, corticosteroids, cytokines, nasal lavage, plasma proteins, serum

Received: February 132004

Accepted after revision: May 122004

This study was supported by Glaxo Smith Kline (Greenford, UK) and the Swedish Council for Work Life Research, the Swedish Farmers' Foundation for Agricultural Research, the Swedish Heart Lung Foundation and the Karolinska Institute (all Stockholm, Sweden).
Exposure in a swine confinement building for $3 \mathrm{~h}$ causes increased airway responsiveness and a massive influx of inflammatory cells into the airways in healthy subjects [1-3]. In bronchoalveolar lavage (BAL) fluid, a 75-fold increase in neutrophil numbers, more than doubling of alveolar macrophage numbers and a three-fold increase in lymphocyte numbers have been found following exposure $[1,2,4]$. In addition, the concentrations of pro-inflammatory cytokines (tumour necrosis factor (TNF)- $\alpha$ and interleukin (IL)-6 and IL-8) are elevated in nasal fluid and BAL fluid following exposure to swine dust $[2,4,5]$. Inhalation of swine dust also causes leakage of plasma proteins into the airways, as assessed by increased levels of $\alpha_{2}$-macroglobulin, transferrin and albumin in BAL fluid [6]. Exposure in swine barns also induces systemic effects, such as increased body temperature and increased plasma levels of acute-phase proteins and IL-6 [1].

Glucocorticoids yield anti-inflammatory effects by modulating gene expression, mediated through the glucocorticoid receptor [7]. An important part of the anti-inflammatory effects of glucocorticoids is repression of inflammatory mediators, particularly cytokines, and inhibition of inflammatory cell migration [8]. It has previously been shown that fluticasone propionate almost totally inhibits swine-dustinduced IL-6 and IL-8 release from epithelial cells in vitro [9]. Additionally, the inhibition by fluticasone propionate of the dust-induced IL-6 and IL-8 release from epithelial cells is, in part, mediated by inhibition of nuclear factor (NF)- $\kappa \mathrm{B}$ activation [10]. However, the precise molecular mechanism of glucocorticoid action is unclear in this context.

Glucocorticoids are thus capable of influencing different indices of the inflammatory process. In addition to the beneficial effects in asthma, inhaled glucocorticoids are also a remedy for other inflammatory airway diseases, such as severe chronic obstructive pulmonary disease. It is, however, not clear whether or not this treatment alters the airway responses to heavy exposure to organic dust. The aim of the present study was, therefore, to investigate whether 2 weeks of treatment with inhaled and intranasally administered fluticasone propionate alters the inflammatory response and the effect on bronchial responsiveness induced by exposure in a swine barn. The airway pulmonary tissue concentration of the steroid during inhalation treatment would be expected to be in the same order of magnitude [11] as that previously found to abolish cytokine release from epithelial cells in vitro [9].

\section{Materials and methods}

\section{Subjects}

A total of 16 healthy nonsmoking subjects ( 12 males) with a mean age of 27 yrs (range 21-46) participated in the study. In order to be considered eligible for participation, all subjects 
were required to show normal results on physical examination, chest radiography and spirometry. They had to have no history of asthma or allergic diseases, as evaluated by a questionnaire. The study was approved by the ethics committee of the Karolinska Institute (Stockholm, Sweden) and was performed with the informed consent of all subjects.

\section{Study design}

The subjects were randomised to either receive fluticasone propionate $(500 \mu \mathrm{g}$ b.i.d. by inhalation and $100 \mu \mathrm{g}$ intranasally once daily, $50 \mu \mathrm{g}$ in each nostril; $\mathrm{n}=7$, one female) or placebo (twice daily by inhalation; $n=8$, two females) for 10-14 days in a single-blind manner. The exposure took place after the last dose $(\sim 1 \mathrm{~h})$ while weighing pigs for $3 \mathrm{~h}$ in a swine barn, containing 700-900 pigs. The participants assisted the farmer and guided the pigs through weighing boxes. Analysis of nasal lavage (NAL) fluids, serum samples and bronchial methacholine responsiveness was performed at different time points before and after exposure, as follows.

\section{Symptoms}

After exposure, symptoms of shivering, headache, malaise, muscle pain and nausea were evaluated by the use of a questionnaire. The symptoms were graded according to severity on a scale of 1-5 (1: no symptoms; 5: severe symptoms). Only grades 4 and 5 were classified as significant. Oral temperature was measured directly before exposure, immediately after exposure and over the next $10 \mathrm{~h}$ at $2-\mathrm{h}$ intervals.

\section{Nasal lavage}

NAL was performed before the start of medication, after 2 weeks of treatment $(1 \mathrm{~h}$ before exposure) and $7 \mathrm{~h}$ after the start of exposure. The NAL procedure described by PIPKORN et al. [12] and BASCOM et al. [13] was used with minor modifications. The subject flexed their neck $45^{\circ}$ backwards and closed the soft palate while $5 \mathrm{~mL} 0.9 \%$ sodium chloride was instilled into one nostril using a needleless syringe. After $10 \mathrm{~s}$, the neck was flexed forwards and the liquid expelled into a plastic basin, which was placed on ice during processing. The procedure was repeated on the other side. The volume of the combined lavage portions was measured and centrifuged for $10 \mathrm{~min}$ at $200 \times \mathrm{g}$ at $4^{\circ} \mathrm{C}$ and the supernatant frozen at $-70^{\circ} \mathrm{C}$ until analysis. The pellet was resuspended in $0.5 \mathrm{~mL}$ $9 \mathrm{mg} \cdot \mathrm{mL}^{-1} \mathrm{NaCl}$ containing $0.1 \%$ human serum albumin and the total number of recovered cells were counted in a Bürker chamber. Cytocentrifuge-prepared slides were stained with May-Grünwald Giemsa stain and 300 cells were assessed for differential cell counts. Less than 100 cells were considered too few cells for an accurate differential count.

\section{Serum}

Blood samples were collected before medication, $1 \mathrm{~h}$ before exposure and 4, 7 and $24 \mathrm{~h}$ after the start of exposure. Blood samples were allowed to coagulate at room temperature for $1 \mathrm{~h}$ before centrifugation $(1,550 \times g$ for $10 \mathrm{~min})$ and the serum was dispensed into several aliquots, which were kept at $-70^{\circ} \mathrm{C}$ until analysis. Each sample underwent only one freeze/thaw cycle before assay.

\section{Analysis}

TNF- $\alpha$ and granulocyte-macrophage colony-stimulating factor (GM-CSF) levels in serum and NAL fluid were analysed using commercial high sensitive sandwich enzyme immunoassay kits (Quantikine ${ }^{\mathrm{TM}}$; R\&D Systems Europe, Abingdon, UK). The detection ranges were $0.5-32 \mathrm{pg} \cdot \mathrm{mL}^{-1}$ for TNF- $\alpha$ and $1-64 \mathrm{pg} \cdot \mathrm{mL}^{-1}$ for GM-CSF. IL-6 and IL- 8 and RANTES (regulated upon activation, normal T-cell expressed and secreted) were measured using an ELISA developed in the authors' laboratory, together with an enzyme-amplified detection system when necessary. The IL-6 analyses were described in detail by EK et al. [14] and the lowest standard concentration was $0.125 \mathrm{pg} \cdot \mathrm{mL}^{-1}$. For analyses of IL-8 and RANTES, commercially available antibody pairs, standards and Quantikine ${ }^{\mathrm{TM}}$ serum controls at three different concentrations (R\&D Systems Europe) were used, and the lower detection limits were 25 and $2.34 \mathrm{pg} \cdot \mathrm{mL}^{-1}$, respectively. Albumin in NAL fluid was quantified by ELISA, as previously described [4]. The lower detection limit of the assay was $0.11 \mu \mathrm{g} \cdot \mathrm{mL}^{-1}$. $\alpha_{2}$-Macroglobulin in NAL fluid was quantified using an ELISA as previously described [6]. The lower detection limit of the assay was $0.5 \mathrm{pg} \cdot \mathrm{mL}^{-1}$. Analysis of leukotriene (LT) $\mathrm{E}_{4}$ in NAL fluid was performed with an enzyme immunoassay using polyclonal antisera and an acetylcholinesterase-linked tracer, as previously described [15]. The detection limit was $7.8 \mathrm{pg} \cdot \mathrm{mL}^{-1}$. For all analyses, duplicates were measured and an intra-assay coefficient of variation of $<10 \%$ and inter-assay coefficient of variation of $<20 \%$ were accepted. Absorbance was measured using a Thermomax 250 reader (Molecular Devices, Sunnyvale, CA, USA).

\section{Lung function tests and methacholine provocation}

Lung function (forced expiratory volume in one second (FEV1) and vital capacity) was measured using a wedge spirometer (Vitalograph $\mathbb{R}$; Medical Instrumentation, Buckingham, UK) according to the criteria of the American Thoracic Society [16]. Local reference values were used [17, 18]. Peak expiratory flow was measured with a mini-Wright peak flow meter (Clement Clarke, London, UK); the best of three blows was registered.

Bronchial responsiveness was assessed by methacholine challenge. Inhalation of diluent was followed by inhalation of doubling methacholine concentrations, starting at $0.5 \mathrm{mg} \cdot \mathrm{mL}^{-1}$ and up to $64 \mathrm{mg} \cdot \mathrm{mL}^{-1}$ or until there was a $20 \%$ fall in FEV1, as previously described [19]. The results were expressed as the provocative concentration (PC20) or cumulative dose (PD20) of methacholine causing a $20 \%$ fall in FEV1. In one subject pre-exposure FEV1 did not fall by $20 \%$ at the maximum concentration. This subject was assigned a PC20 of $65 \mathrm{mg} \cdot \mathrm{mL}^{-1}$ for nonparametric statistical calculations.

The methacholine provocation and lung function tests were performed $\sim 1-2$ weeks before medication and $4 \mathrm{~h}$ after cessation of exposure in the swine house.

\section{Exposure measurements}

Total dust and endotoxin levels were measured in inhalable and respirable dust as previously described [14].

\section{Statistics}

Oral temperatures and lung function data are presented as mean $\pm \mathrm{SEM} / \mathrm{SD}$, as indicated, and comparisons were made 
using ANOVA and/or a t-test. Data on bronchial responsiveness, cell count, soluble products in NAL fluid and serum (except for IL-6) are given as median (interquartile range), and comparisons were made using the Wilcoxon signedrank-sum test and Mann-Whitney U test. Serum levels of IL-6 were compared by ANOVA and t-tests after confirmation of normal distribution of pre-exposure data ( Z-score). A p-value of $<0.05$ was considered significant. Spearman rank coefficients (rho) were calculated for correlations. Concentrations below the detection limits were assigned a fixed value slightly lower than the lower detection limit for statistical comparisons.

\section{Results}

One subject in the fluticasone group was excluded from all analyses due to an upper airway infection that commenced during the pre-exposure treatment period. In addition to severe symptoms of airway infection, all inflammatory marker levels measured were highly elevated $1 \mathrm{~h}$ prior to exposure compared to the pre-treatment values obtained 2 weeks previously in this subject.

\section{Symptoms}

Five of the eight participants in the placebo group and two of the seven in the fluticasone group experienced symptoms (grades 4 and 5) following exposure. Two participants in the placebo group experienced shivering, one headache and two malaise, and the two individuals in the fluticasone group experienced malaise.

Oral temperature was $35.9 \pm 0.5$ and $35.9 \pm 0.3^{\circ} \mathrm{C}($ mean \pm SD) immediately before exposure in the placebo and fluticasone groups respectively (fig. 1). The temperature increased after exposure in both groups to a maximum 9-11 h after exposure $(\mathrm{p}<0.01)$. The increase in temperature was significantly lower in the fluticasone group than in the placebo group $(\mathrm{F}=3.5$, $\mathrm{p}=0.007)$.

\section{Nasal lavage fluid}

In the placebo group, exposure caused a significant increase in total cell $(\mathrm{p}=0.01)$ and neutrophilic granulocyte

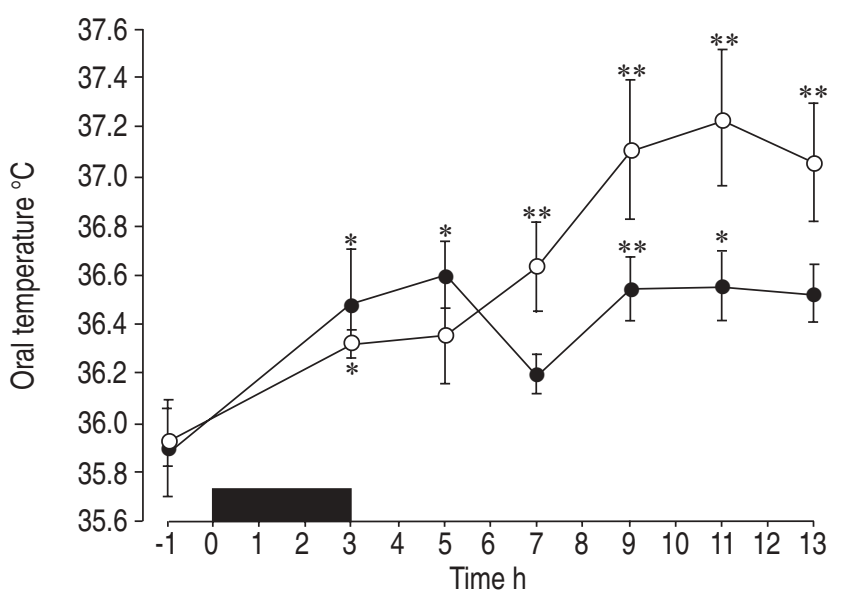

Fig. 1.-Oral temperature in healthy subjects before and after exposure ) in a swine house. The subjects were treated with placebo $(\bigcirc ; n=8)$ or fluticasone propionate $(\boldsymbol{O} ; \mathrm{n}=7)$ for 2 weeks prior to exposure. Data are presented as mean \pm SEM. The increase in body temperature was significantly smaller in the fluticasone group than in the placebo group $(\mathrm{F}=3.5, \mathrm{p}=0.007){ }^{*}: \mathrm{p}<0.05 ; * *: \mathrm{p}<0.01$ versus pre-exposure values. concentration $(\mathrm{p}=0.02)$, whereas no significant changes in total cell $(\mathrm{p}=0.5)$ or neutrophil concentration $(\mathrm{p}=0.18)$ were found in the fluticasone group (fig. 2, table 1). There was, however, no significant difference between the groups with regard to total cell $(\mathrm{p}=0.3)$ or neutrophil concentration $(\mathrm{p}=0.4)$.

There was a significant increase in IL-6 and IL-8 and TNF- $\alpha$ levels after exposure, whereas $\mathrm{LTE}_{4}$, albumin and $\alpha_{2}$-macroglobulin levels increased significantly only in the placebo group (fig. 2). There were significantly lower increases in the fluticasone group with regard to IL-8 ( $p=0.02)$, TNF- $\alpha$ $(p=0.03)$ and albumin $(p=0.02)$. GM-CSF concentrations in NAL fluid ( $1 \mathrm{~h}$ before and $7 \mathrm{~h}$ after exposure) were below the detection limit $\left(<1 \mathrm{pg} \cdot \mathrm{mL}^{-1}\right)$ in both groups. The RANTES concentration in NAL fluid was below the detection limit $\left(<2.3 \mathrm{pg} \cdot \mathrm{mL}^{-1}\right)$ in 14 of the 16 subjects before medication, in 13 of the 16 subjects before exposure and in 10 of the 16 subjects after exposure.

There were significant correlations between post-exposure increases in levels of albumin and of $\alpha_{2}$-macroglobulin (rho=0.79, p=0.003), IL-8 (rho=0.90, p=0.0007), TNF- $\alpha$ (rho=0.84, p=0.004) and $\mathrm{LTE}_{4}$ (rho=0.92, p=0.004) (fig. 3).

\section{Serum}

The concentration of IL-6 in serum increased significantly in both groups $(\mathrm{p}<0.05)$, with a lesser increase in the fluticasone group $(\mathrm{F}=3.2, \mathrm{p}=0.03)$ (fig. 4). In the placebo group (but not in the fluticasone group), there was a correlation between the maximum increase in serum IL-6 concentration and the maximum increase in body temperature (rho=0.79, $\mathrm{p}=0.04$ ). The serum concentration of TNF- $\alpha$ $1 \mathrm{~h}$ before exposure was $2.0(1.9-2.2) \mathrm{pg} \cdot \mathrm{mL}^{-1}$ in the placebo group and $2.6(1.5-2.8) \mathrm{pg} \cdot \mathrm{mL}^{-1}$ in the fluticasone group, and did not change after exposure. The RANTES concentrations $1 \mathrm{~h}$ before exposure were $71(51-83) \mathrm{ng} \cdot \mathrm{mL}^{-1}$ in the placebo group and $71(67-79) \mathrm{ng} \cdot \mathrm{mL}^{-1}$ in the fluticasone group, and did not change after exposure. Exposure or medication did not significantly affect the serum concentrations of TNF- $\alpha$ or RANTES. GM-CSF concentrations in serum were below the detection limit $\left(<1 \mathrm{pg} \cdot \mathrm{mL}^{-1}\right)$ in all but one subject.

\section{Lung function}

Exposure caused a slight but significant decrease in vital capacity and FEV1 in all subjects, and there was no significant difference between the groups (table 2).

\section{Methacholine provocation}

Bronchial responsiveness to methacholine increased significantly in both groups after swine house exposure, with no significant difference between the groups $(\mathrm{p}=0.4)$ (fig. 5$)$. In the placebo group, the PD20 fell from $1.90(1.24-5.23) \mathrm{mg}$ before to $0.25(0.08-0.35) \mathrm{mg}$ after exposure $(\mathrm{p}=0.01)$ and, in the fluticasone group, from $1.39(0.52-2.34) \mathrm{mg}$ before to 0.12 $(0.08-0.15) \mathrm{mg}$ after exposure $(\mathrm{p}=0.02)$. Thus bronchial responsiveness to methacholine increased by $3.2(2.8-4.1)$ doubling concentration steps in the placebo group and 2.5 (1.5-3.9) doubling concentration steps in the fluticasone group.

\section{Exposure measurements}

The concentration of inhalable dust, assessed by the use of personal samplers, was $27.2(19.8-36.4) \mathrm{mg} \cdot \mathrm{m}^{-3}, 842$ $(396-1,197) \mathrm{ng} \cdot \mathrm{m}^{-3}$ of which was the endotoxin concentration. 

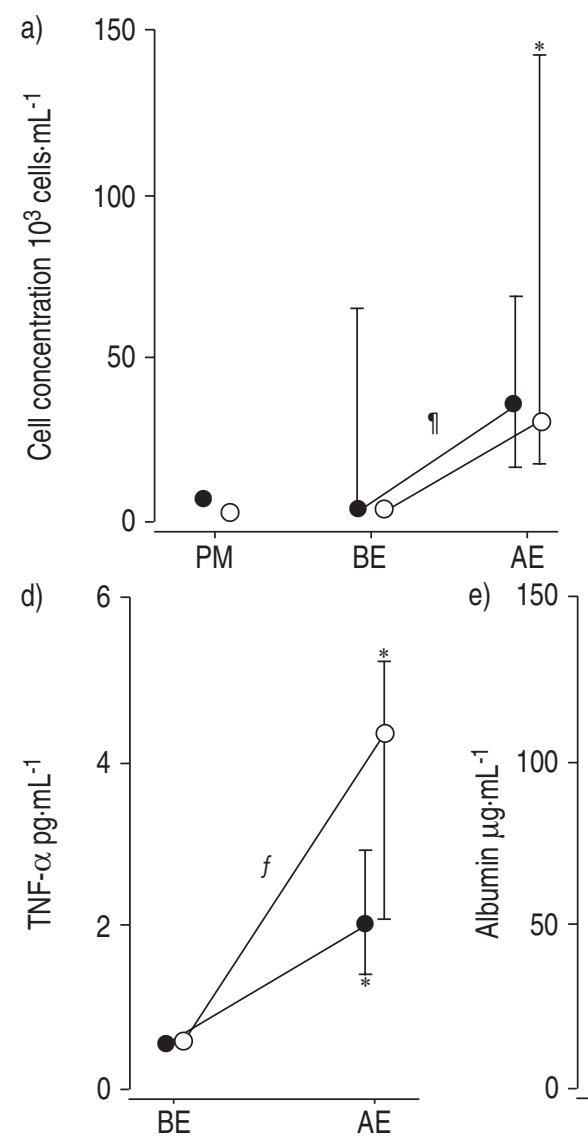

e) 150
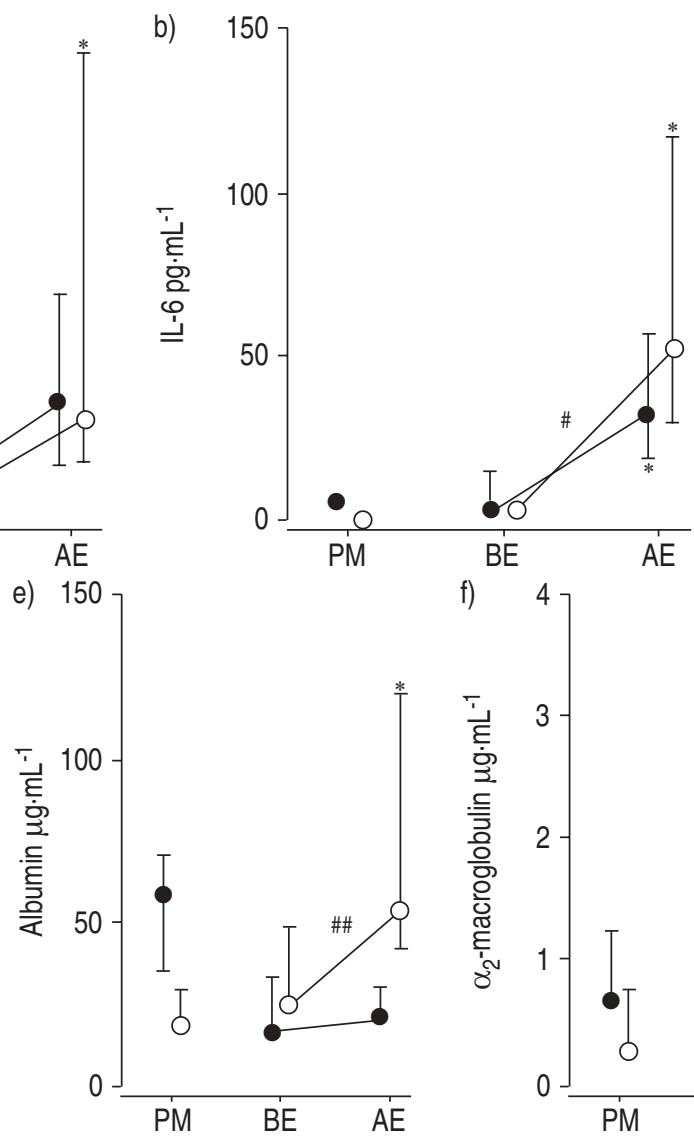
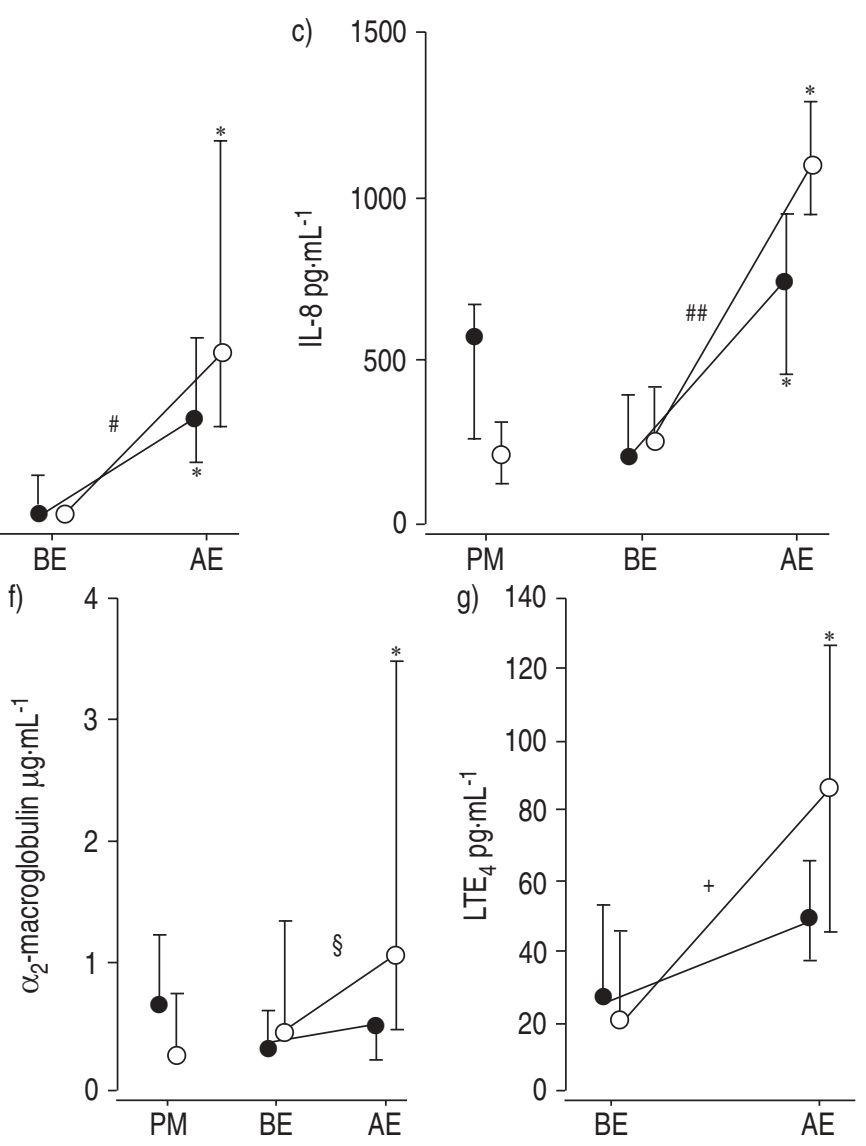

Fig. 2. - Analysis of nasal lavage fluid from healthy subjects before and after exposure in a swine house: a) cell concentration, and b-g) concentrations of b) interleukin (IL)-6, c) IL-8, d) tumour necrosis factor (TNF)- $\alpha$, e) albumin, f) $\alpha_{2}$-macroglobulin, and g) leukotriene (LT) $E_{4}$. The subjects were treated with placebo $\left(\bigcirc ; n=8 ; n=6\right.$ for $L_{T E}$ analysis $)$ or fluticasone propionate $\left(\bullet ; n=7 ; n=5\right.$ for $L T E_{4}$ analysis $)$ for 2 weeks before exposure. Owing to the limited volume of lavage fluid, only $11 \mathrm{LTE}_{4}$ analyses could be performed. Data are presented as median (interquartile range). Fluticasone propionate treatment did not significantly alter concentrations of cells IL-6, IL-8, albumin or $\alpha_{2}$-macroglobulin before exposure. PM: premedication; BE: before exposure; AE: after exposure. ${ }^{*}: \mathrm{p}<0.05$ versus pre-exposure values; ${ }^{\#}: \mathrm{p}=0.6 ;{ }^{\uparrow}: \mathrm{p}=0.3 ;{ }^{+}: \mathrm{p}=0.07$; s: $\mathrm{p}=0.06 ;{ }^{f}: \mathrm{p}=0.03 ;{ }^{\# \#}: \mathrm{p}=0.02$ difference between groups before and after exposure.

The concentration of respirable dust was $0.98(0.72-1.27)$ $\mathrm{mg} \cdot \mathrm{m}^{-3}, 33(15-51) \mathrm{ng} \cdot \mathrm{m}^{-3}$ of which was the endotoxin concentration [14]. There were no significant differences in exposure between the groups.

\section{Discussion}

In the present study, it has been demonstrated that 2 weeks of fluticasone propionate treatment significantly attenuated the systemic effects induced by exposure to organic dust in a swine barn. Thus, the increase in body temperature and serum IL-6 levels after exposure were significantly lower in the fluticasone group than in the placebo group. Furthermore, intranasally administered fluticasone propionate had a major influence on the exposure-induced plasma leakage into the upper airways and significantly attenuated the nasal IL-8 and TNF- $\alpha$ response. However, fluticasone propionate inhalation did not alter the increased bronchial responsiveness to methacholine induced by exposure.

Table 1.-Nasal lavage fluid cell densities before and after exposure in a swine house ${ }^{\#}$, in subjects treated with placebo or fluticasone propionate

\begin{tabular}{lccc}
\hline & Premedication & $1 \mathrm{~h}$ before exposure & $7 \mathrm{~h}$ after exposure \\
\hline $\begin{array}{l}\text { Neutrophils } 10^{6} \text { cells } \cdot \mathrm{mL}^{-1} \\
\quad \text { Placebo }\end{array}$ & $0.2(0.0-4.1)$ & $0.0(0.0-1.1)$ & $17.9(10.4-159.5)$ \\
$\quad \begin{array}{l}\text { Fluticasone propionate } \\
\text { Epithelial cells } 10^{6} \text { cells } \cdot \mathrm{mL}^{-1}\end{array}$ & $0.0(0.0-0.9)$ & $0.3(0.0-16.7)$ & $31.1(15.3-66.8)$ \\
$\quad$ Placebo & $1.1(0.1-2.0)$ & $1.2(0.0-7.6)$ & 0.02 \\
$\quad$ Fluticasone propionate & $0.0(0.0-2.0)$ & $2.3(0.3-13.3)$ & $1.6(0.2-7.1)$ \\
\hline
\end{tabular}

Cell differential counts were not possible in all lavage fluids due to low cell concentrations; therefore, seven premedication lavages and five lavages performed $1 \mathrm{~h}$ before exposure were assigned a cell concentration of $0 \times 10^{6}$ cells $\cdot \mathrm{L}^{-1}$. Data from one subject in the placebo group were omitted due to technical problems in one lavage. Data are presented as median (interquartile range) ( $\mathrm{n}=7$ for both groups). The cellular reaction was not significantly different between the groups ( $\mathrm{p}=0.4$ for both neutrophils and epithelial cells). ${ }^{\#}$ : before medication, $1 \mathrm{~h}$ before exposure and $7 \mathrm{~h}$ after exposure; ${ }^{\circ}$ : for 2 weeks prior to exposure; ${ }^{+}: 1 \mathrm{~h}$ before exposure versus $7 \mathrm{~h}$ after exposure. 

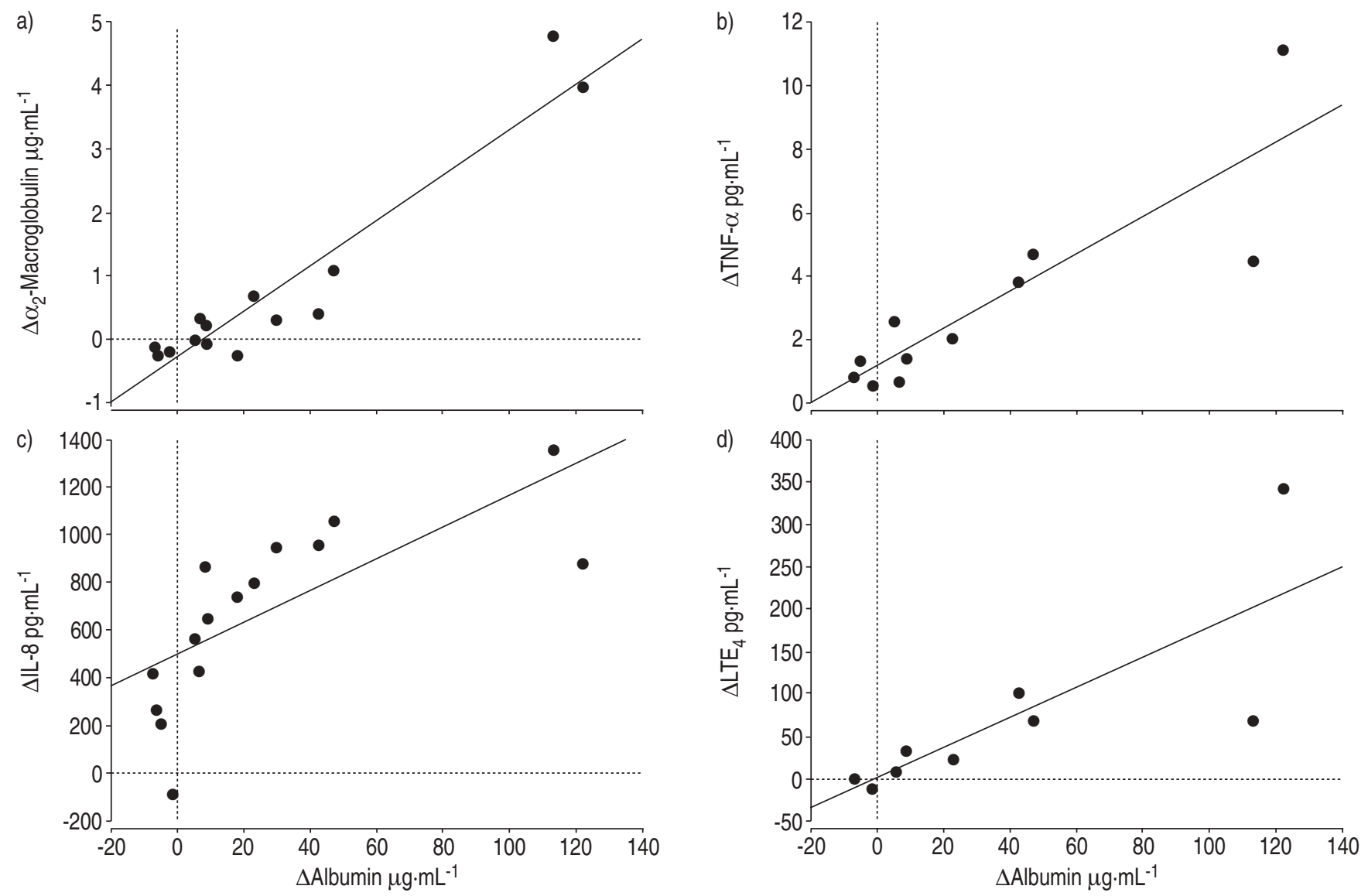

Fig. 3.-Correlations between differences ( $\Delta$ : after exposure-before exposure) in nasal lavage fluid (whole material) levels of albumin and: a) $\alpha_{2}$-macroglobulin (rho=0.79, $\mathrm{p}=0.003$ ), b) tumour necrosis factor (TNF)- $\alpha$ (rho=0.84, $\mathrm{p}=0.004$ ), c) interleukin (IL)-8 (rho=0.90, $\left.\mathrm{p}=0.0007\right)$, and d) leukotriene $(\mathrm{LT}) \mathrm{E}_{4}(\mathrm{rho}=0.92, \mathrm{p}=0.004)\left(\mathrm{n}=15\left(\mathrm{n}=11\right.\right.$ for $\mathrm{LTE}_{4}$ analysis $)$ ).

Exposure in swine houses causes airway inflammation with an increase in levels of inflammatory mediators, such as IL-6, in lavage fluid and blood [4]. Therefore, there is reason to believe that the airway is the source of the elevated IL-6 levels found in blood. IL-6 is an endogenous circulating pyrogen,

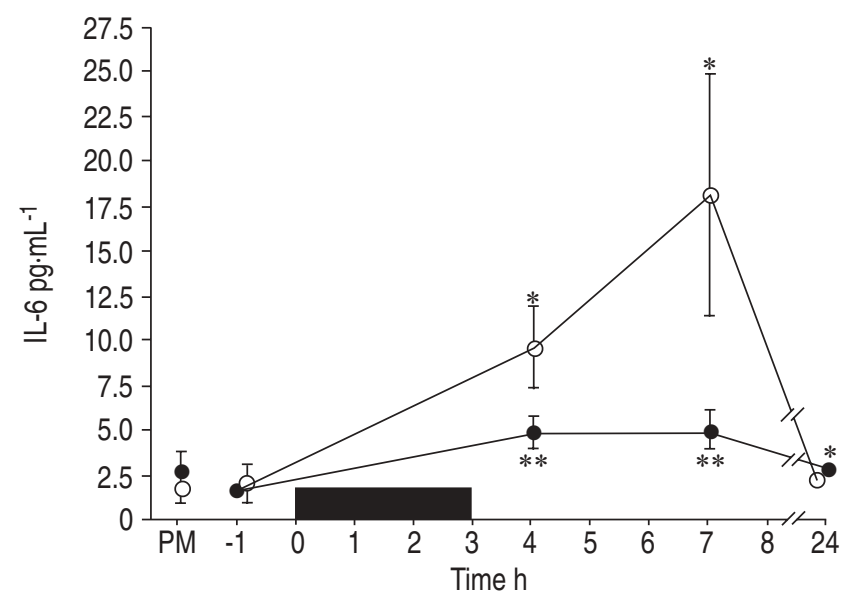

Fig. 4.-Interleukin (IL)-6 concentrations in serum from healthy subjects before and after exposure (ם) in a swine house. The subjects were treated with placebo $(O ; n=8)$ or fluticasone propionate $(\boldsymbol{O}$; $\mathrm{n}=7$ ) for 2 weeks prior to $3 \mathrm{~h}$ of exposure. Data are presented as median (interquartile range). There is a significant difference between the groups $(\mathrm{F}=3.2, \mathrm{p}=0.03)$. $\mathrm{PM}$ : premedication. *: $\mathrm{p}<0.05 ; * *: \mathrm{p}<0.01$ versus pre-exposure values (1 $\mathrm{h}$ before exposure). responsible for induction of fever during infection and inflammation [20]; increased levels of IL-6 are found in the blood of patients following injury and correlate significantly with the increase in body temperature [21]. In the present study, a correlation was found between the maximal increase in serum IL-6 level and body temperature after exposure in the placebo group but not in the fluticasone group. Therefore, a causal relationship might exist between the post-exposure attenuation of serum IL-6 level and body temperature in the fluticasone group. Fluticasone propionate, however, did not alter IL-6 release neither in the nose (NAL) nor, as previously demonstrated [14], in the lungs following exposure. One reason for this could be that the major source of serum IL-6 might be the lower airways and BAL was performed too late (24 h after exposure) to detect a possible steroid-mediated effect on airway IL- 6 release in that study. Recent unpublished findings in the present study laboratory support such a hypothesis, demonstrating that IL-6 release and expression decline in epithelial cells after a few hours of exposure to swine house dust in vitro. It has previously been shown that fluticasone propionate inhibits IL-6 secretion from alveolar macrophages stimulated by lipopolysaccharide and abolish IL-6 secretion from swine dust-stimulated epithelial cells at a concentration $\left(1 \times 10^{-9} \mathrm{M}\right)$ that can be anticipated to occur in lung tissue during treatment with the doses used in the present study $[9,11]$. In addition, it has recently been shown that the transcription factor NF- $\kappa \mathrm{B}$ is involved in organic-dustmediated cytokine release (IL-6 and IL-8) from epithelial cells, and that inhibition of IL- 6 and IL- 8 release by glucocorticoids is, in part, mediated by inhibition of this 
Table 2. - Lung function before and after exposure in a swine house ${ }^{\#}$ in subjects treated with placebo or fluticasone propionate

\begin{tabular}{|c|c|c|c|c|c|}
\hline & $\begin{array}{c}\text { Subjects } \\
\mathrm{n}\end{array}$ & $\begin{array}{l}\text { Pre-exposure } \\
\text { VC } \% \text { pred }\end{array}$ & $\begin{array}{c}\text { Post-exposure } \\
\Delta \text { VC } \%\end{array}$ & $\begin{array}{l}\text { Pre-exposure } \\
\text { FEV1\% pred }\end{array}$ & $\begin{array}{c}\text { Post-exposure } \\
\Delta \text { FEV1 } \%\end{array}$ \\
\hline Placebo & 8 & $89.1 \pm 10.0$ & $-3.6 \pm 2.9 * *$ & $95.1 \pm 7.3$ & $-7.8 \pm 4.1 * *$ \\
\hline Fluticasone propionate & 7 & $97.1 \pm 7.9$ & $-1.9 \pm 1.5^{*}$ & $99.9 \pm 12.0$ & $-4.9 \pm 2.6^{* *}$ \\
\hline Between-group p-value & & & 0.4 & & 0.4 \\
\hline
\end{tabular}

Data are presented as mean $\pm \mathrm{SD}$; There was no significant difference between the groups (t-test); VC: vital capacity; $\Delta$ : change; FEV1: forced expiratory volume in one second. "\#: before medication and $7 \mathrm{~h}$ after exposure; ${ }^{\top}$ : for 2 weeks prior to exposure; *: $\mathrm{p}<0.05$; **: $\mathrm{p}<0.01$ versus preexposure values.

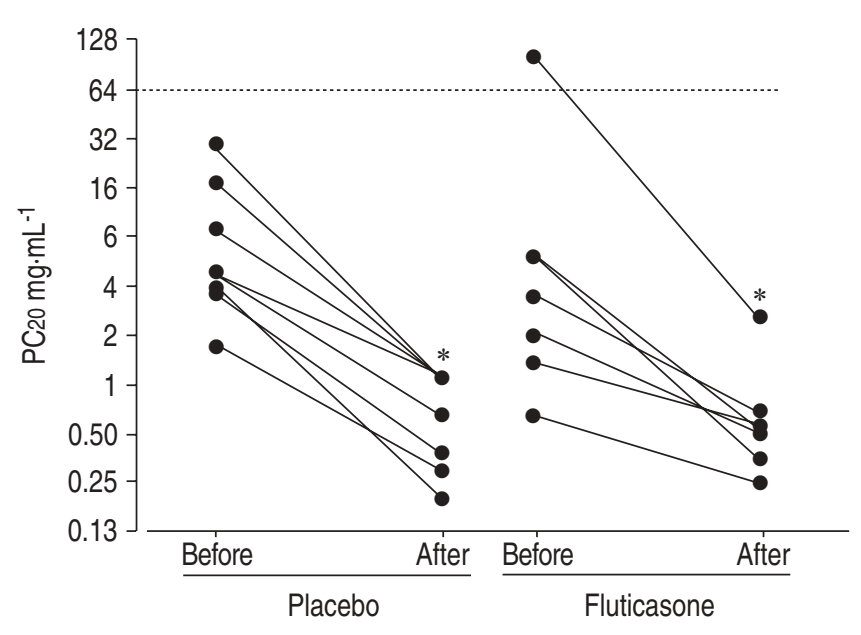

Fig. 5.- Bronchial responsiveness to methacholine before medication and $7 \mathrm{~h}$ after the start of the exposure in a swine house in healthy subjects pretreated with placebo $(n=8)$ or fluticasone propionate $(n=7)$ during the 2 weeks prior to exposure $(\cdots \cdots$ : highest inhaled concentration of methacholine). The change in bronchial responsiveness calculated from the decrease in doubling concentration steps did not significantly differ between the groups $(p=0.4)$. PC20: provocative concentration of methacholine causing a $20 \%$ fall in forced expiratory volume in one second. *: $\mathrm{p}<0.05$ versus pre-exposure values.

mechanism [10]. These in vitro data are in agreement with the finding of lower IL-6 levels following exposure in the subjects who were treated with glucocorticoids. The effect on serum IL-6 might explain the attenuated increase in post-exposure body temperature in the steroid-treated group.

Topical fluticasone propionate treatment inhibited the organic-dust-induced increase in IL- 8 and TNF- $\alpha$ levels in NAL fluid following organic dust exposure, which is consistent with previous findings in vitro $[9,10]$. Neutrophilic granulocytes, which increase substantially in number after exposure [2], may, in addition to epithelial cells, be an important source of IL- 8 and TNF- $\alpha$, since both cell types are capable of producing both cytokines [22]. In a recent study, glucocorticoids were found to be important inhibitors of IL-8 release from neutrophils in vitro [23]. Mast cells are also important sources of TNF- $\alpha$ and IL-8 production [24]. Mast cells seem to play a role in the organic-dust-mediated airway inflammatory response since urinary excretion of $9 \alpha, 11 \beta$ prostaglandin $F_{2}$, a prostaglandin $D_{2}$ metabolite that is almost exclusively produced by mast cells, increases after exposure [25]. In addition, inhalation of sodium cromoglycate alters the inflammatory reaction to swine dust exposure, probably by interacting with mast cells [26]. It was recently shown that dexamethasone potently inhibits TNF- $\alpha$ production by activated mast cells in vitro [27]. It is thus possible that fluticasone propionate treatment attenuates the organic-dust-induced cytokine level increase by interaction with epithelial cells and other cell types, such as mast cells and/or neutrophils.
Topical fluticasone propionate treatment also inhibited the leakage of plasma proteins (albumin and $\alpha_{2}$-macroglobulin) into NAL fluid following organic dust exposure. This finding indicates a major effect on plasma leakage induced by exposure and confirms previous data showing that glucocorticoids inhibit plasma exudation in inflammatory airways diseases [28]. It is not known whether the anti-exudative efficacy of glucocorticoids in rhinitis and asthma [29, 30] reflects a direct effect of glucocorticoids on the microvascular wall in human airways or whether it reflects indirect action on cellular inflammatory responses. The possibility of direct action on the microvascular wall has been demonstrated in animal experiments [31]. However, budesonide treatment did not affect the histamine-induced mucosal exudation of albumin in humans and it has, therefore, been claimed that the anti-exudative efficacy of topical glucocorticoids in airway disease reflects the ability of these drugs to suppress cellular mechanisms [32]. A relationship was found between the release of IL- 8 or $\mathrm{LTE}_{4}$ and albumin and $\alpha_{2}$-macroglobulin into NAL fluid. The increased vascular permeability observed under inflammatory conditions is suggested to be driven by cysteinyl LTs [33] and possibly IL-8, which may also induce plasma exudation [34]. It is thus possible that the IL-8 and $\mathrm{LTE}_{4}$ released after exposure contribute to the plasma exudation observed, and the significant inhibition of exposure-induced IL-8 release by fluticasone propionate might, in part, lead to the inhibition of plasma leakage.

No effect of fluticasone propionate treatment on the increase in methacholine-induced airway responsiveness induced by exposure in a swine barn was found in healthy subjects. A recent meta-analysis on the dose/response relationship between inhaled corticosteroids and bronchial hyperresponsiveness in asthmatic subjects showed that glucocorticoids reduce airway hyperresponsiveness to methacholine by $0.45-3.47$ doubling dose steps and that high doses confer greater improvement than low doses [35]. However, the factors predictive of improvement in bronchial hyperresponsiveness with inhaled glucocorticoids are still largely unknown, and the relationship between inflammation and bronchial hyperresponsiveness is not clear. In agreement with the present findings, NightingALE et al. [36] found that inhaled budesonide did not protect against neither the ozone-induced increase in methacholine reactivity nor the increase in sputum neutrophil numbers in normal subjects.

In conclusion, it was found that glucocorticoid treatment attenuated the upper airway response and the systemic response to inhaled organic dust without affecting the increased bronchial responsiveness.

Acknowledgements. Fluticasone propionate and placebo were generously provided by Glaxo Smith Kline (Greenford, UK). The authors would like to thank K-G. Kölbeck for work with subjects, S. Siljerud, C. Müller-Suur, B-M. Larsson, B-M. Sundblad, H. Saranius and I. Dehlin for skilful technical assistance and M. Kumlin for valuable advice. 


\section{References}

1. Larsson KA, Eklund AG, Hansson LO, Isaksson BM, Malmberg PO. Swine dust causes intense airways inflammation in healthy subjects. Am J Respir Crit Care Med 1994; 150: 973-977.

2. Larsson BM, Palmberg L, Malmberg PO, Larsson K. Effect of exposure to swine dust on levels of IL-8 in airway lavage fluid. Thorax 1997; 52: 638-642.

3. Malmberg P, Larsson K. Acute exposure to swine dust causes bronchial hyperresponsiveness in healthy subjects. Eur Respir J 1993; 6: 400-404.

4. Wang Z, Larsson K, Palmberg L, Malmberg P, Larsson P, Larsson L. Inhalation of swine dust induces cytokine release in the upper and lower airways. Eur Respir J 1997; 10: 381387.

5. Wang Z, Malmberg P, Larsson P, Larsson BM, Larsson K. Time course of interleukin- 6 and tumor necrosis factor- $\alpha$ increase in serum following inhalation of swine dust. $\mathrm{Am}$ J Respir Crit Care Med 1996; 153: 147-152.

6. Vesterberg O, Palmberg L, Larsson K. Albumin, transferrin and $\alpha_{2}$-macroglobulin in bronchoalveolar lavage fluid following exposure to organic dust in healthy subjects. Int Arch Occup Environ Health 2001; 74: 249-254.

7. Umland SP, Schleimer RP, Johnston SL. Review of the molecular and cellular mechanisms of action of glucocorticoids for use in asthma. Pulm Pharmacol Ther 2002; 15: 3550 .

8. Barnes P. Anti-inflammatory actions of glucocorticoids: molecular mechanisms. Clin Sci 1998; 94: 557-572.

9. Ek A, Larsson K, Siljerud S, Palmberg L. Fluticasone and budesonide inhibit cytokine release in human lung epithelial cells and alveolar macrophages. Allergy 1999; 54: 691-699.

10. Liden J, Ek A, Palmberg L, Okret S, Larsson K. Organic dust activates NF- $\kappa \mathrm{B}$ in lung epithelial cells. Respir Med 2003; 97: 882-892.

11. Van den Bosch JM, Westermann CJ, Aumann J, Edsbacker $\mathrm{S}$, Tonnesson M, Selroos O. Relationship between lung tissue and blood plasma concentrations of inhaled budesonide. Biopharm Drug Dispos 1993; 14: 455-459.

12. Pipkorn U, Karlsson G, Enerback L. A brush method to harvest cells from the nasal mucosa for microscopic and biochemical analysis. J Immunol Methods 1988; 112: 37-42.

13. Bascom R, Pipkorn U, Lichtenstein LM, Naclerio RM. The influx of inflammatory cells into nasal washings during the late response to antigen challenge. Effect of systemic steroid pretreatment. Am Rev Respir Dis 1988; 138: 406-412.

14. Ek A, Palmberg L, Larsson K. Influence of fluticasone and salmeterol on airway effects of inhaled organic dust: an in vivo and ex vivo study. Clin Exp Immunol 2000; 121: 11-16.

15. Kumlin M, Stensvad F, Larsson L, Dahlen B, Dahlen SE. Validation and application of a new simple strategy for measurements of urinary leukotriene $\mathrm{E}_{4}$ in humans. Clin Exp Allergy 1995; 25: 467-479.

16. American Thoracic Society. Standardization of Spirometry, 1994 Update. Am J Respir Crit Care Med 1995; 152: 11071136.

17. Hedenstrom H, Malmberg P, Fridriksson HV. Reference values for lung function tests in men: regression equations with smoking variables. Ups J Med Sci 1986; 91: 299-310.

18. Hedenstrom H, Malmberg P, Agarwal K. Reference values for lung function tests in females. Regression equations with smoking variables. Bull Eur Physiopathol Respir 1985; 21: $551-557$.
19. Sundblad BM, Palmberg L, Larsson K. Bronchial responsiveness to eucapnic hyperventilation and methacholine following exposure to organic dust. Chest 2002; 122: 363368.

20. Luheshi G, Rothwell N. Cytokines and fever. Int Arch Allergy Immunol 1996; 109: 301-307.

21. Nijsten MW, de Groot ER, ten Duis HJ, Klasen HJ, Hack CE, Aarden LA. Serum levels of interleukin-6 and acute phase responses. Lancet 1987; 2: 921.

22. Cassatella MA, Gasperini S, Russo MP. Cytokine expression and release by neutrophils. Ann N Y Acad Sci 1997; 832: 233242.

23. Irakam A, Miskolci V, Vancurova I, Davidson D. Doserelated inhibition of proinflammatory cytokine release from neutrophils of the newborn by dexamethasone, betamethasone, and hydrocortisone. Biol Neonate 2002; 82: 89-95.

24. Hart PH. Regulation of the inflammatory response in asthma by mast cell products. Immunol Cell Biol 2001; 79: 149-153.

25. O'Sullivan S, Dahlen SE, Larsson K, et al. Exposure of healthy volunteers to swine house dust increases formation of leukotrienes, prostaglandin $\mathrm{D}_{2}$, and bronchial responsiveness to methacholine. Thorax 1998; 53: 1041-1046.

26. Larsson K, Larsson BM, Sandstrom T, Sundblad BM, Palmberg L. Sodium cromoglycate attenuates pulmonary inflammation without influencing bronchial responsiveness in healthy subjects exposed to organic dust. Clin Exp Allergy 2001; 31: 1356-1368.

27. Smith SJ, Piliponsky AM, Rosenhead F, Elchalal U, Nagler A, Levi-Schaffer F. Dexamethasone inhibits maturation, cytokine production and Fc $\epsilon$ RI expression of human cord blood-derived mast cells. Clin Exp Allergy 2002; 32: 906-913.

28. Svensson C, Klementsson H, Andersson M, Pipkorn U, Alkner U, Persson CG. Glucocorticoid-induced attenuation of mucosal exudation of fibrinogen and bradykinins in seasonal allergic rhinitis. Allergy 1994; 49: 177-183.

29. Rogers DF, Evans TW. Plasma exudation and oedema in asthma. Br Med Bull 1992; 48: 120-134.

30. Nocker RE, Weller FR, Out TA, de Riemer MJ, Jansen HM, van der Zee JS. A double-blind study on the effect of inhaled corticosteroids on plasma protein exudation in asthma. Am J Respir Crit Care Med 1999; 159: 1499-1505.

31. Erjefalt I, Persson CG. Anti-asthma drugs attenuate inflammatory leakage of plasma into airway lumen. Acta Physiol Scand 1986; 128: 653-654.

32. Greiff L, Andersson M, Svensson C, Alkner U, Persson CG. Glucocorticoids may not inhibit plasma exudation by direct vascular antipermeability effects in human airways. Eur Respir J 1994; 7: 1120-1124.

33. Joris I, Majno G, Corey EJ, Lewis RA. The mechanism of vascular leakage induced by leukotriene $\mathrm{E}_{4}$. Endothelial contraction. Am J Pathol 1987; 126: 19-24.

34. Rampart M, Van Damme J, Zonnekeyn L, Herman AG. Granulocyte chemotactic protein/interleukin-8 induces plasma leakage and neutrophil accumulation in rabbit skin. Am J Pathol 1989; 135: 21-25.

35. Currie GP, Fowler SJ, Lipworth BJ. Dose response of inhaled corticosteroids on bronchial hyperresponsiveness: a meta-analysis. Ann Allergy Asthma Immunol 2003; 90: 194198.

36. Nightingale JA, Rogers DF, Fan Chung K, Barnes PJ. No effect of inhaled budesonide on the response to inhaled ozone in normal subjects. Am J Respir Crit Care Med 2000; 161: 479-486. 